Asia Pacific Journal of Contemporary Education and Communication Technology

ISBN (eBook): 9780994365682 । ISSN : 2205-6181

Year: 2017 , Volume: 3, Issue: 2

A P I A R

\title{
THE COMPETENCY BASED TRAINING (CBT) CONCEPT OF TEACHING AND LEARNING IN THE TECHNICAL UNIVERSITIES IN GHANA: CHALLENGES AND THE WAY FORWARD
}

\author{
Prince Charles Acquaha, Elijah Boadu Frimpongb, Julius Kwame Borkloe ${ }^{c}$ \\ abc Kumasi Technical University, P. O. Box 854, Kumasi, Ghana \\ Corresponding email: acquahprince@yahoo.com
}

\begin{abstract}
Competency Based Training (CBT) concept of teaching and learning introduced in the technical universities in Ghana has proven to be a very important educational programme in the technical and vocational education in Ghana. It has greatly improved the employability skills of graduates from the technical universities who have gone through this training and it is also helping to address the shortage of skilled and competent workforce needed in the country. In spite of its importance and prospects, there are some challenges in the CBT implementation that require urgent attention. This paper therefore seeks to address these challenges in the CBT concept. Twenty-five (25) academic staff across eight (8) out of the ten (10) technical universities in Ghana were interviewed. The findings revealed that inadequate funding, lack of infrastructural support and lack of policy guidelines and institutional support are the major challenges in the implementation process. The paper discusses these challenges and concludes with some recommendations that would help to improve the CBT concept of teaching and learning in technical universities in particular and the technical and the vocational education in Ghana in general.
\end{abstract}

Keywords: Competency Based Training, Technical University, Ghana Education, CBT Challenges.

\section{Introduction}

The polytechnic education in Ghana has gone through many transformational changes since its establishment in the early sixties (1960s), all with the aim of addressing deficiencies identified in the system. These have resulted in the introduction of many educational reforms, passage of laws and policy alignment in the sector. These reforms started by the re-designation of some technical institutes in the country as polytechnics in 1963 to train craftsmen for the growing industries in the country (Boakye-Agyeman, 2006). The promulgation of the polytechnics law 1992 (PNDCLaw 321) then gave the legal backing for the establishment of the polytechnics and also elevated six of the existing polytechnics to tertiary status. Four other polytechnics were later established to bring the number to ten (10). The aim; therefore, was to position and align the polytechnics to fully carry out their mandate in the educational system. This notwithstanding, there still remained some deficiencies in the polytechnic education system that needed urgent attention. The deficiency in the traditional subject based system of teaching and learning which does not give students the opportunity to demonstrate the skills and knowledge they acquire during the training session was a major concern to many stakeholders. Educators on the other hand, also find it difficult to assess the competency levels of their students. The Competency Based Training (CBT) concept was therefore introduced to address this deficiency in the current 
system of teaching and learning by replacing the subject base approach to the problem base approach in the technical universities. The CBT concept places more emphasis on achieving benchmarked standards of performance during the entire training session and also puts premium on what a person will do in the workplace after completion of training (ACCI, 1992). The latest reform is the conversion of polytechnics into technical universities in 2016 by the passage of the technical university Act (Act 2016).

The CBT approach to teaching and learning is currently gaining popularity among many stakeholders in the education circles. The ideas of competency are spreading far beyond a single discipline and have been accepted by almost everyone (Butova, 2015). The piloting of CBT concept of teaching in some selected programmes in the technical universities in Ghana has indeed had many successes and challenges as well. CBT has greatly improved the employability skills of students who have gone through this training and it is also helping to address the shortages of skilled workers needed to feed the industry as the economy improves. The successful introduction of CBT to all programmes in the technical universities therefore requires the need to review and assess the entire system and come out with recommendations to address the implementation challenges. The study interviewed twenty- five(25) academic staff, comprises three (3) deans of engineering, five (5) heads of departments, ten (10) lecturers and seven (7) technicians across eight(8) out of the ten (10)technical universities in the country. The aim was to find out from these stakeholders, the major challenges of CBT implementation in their respective departments where CBT has been piloted for over a decade now. This paper highlights the summary of findings from the research and further explains these challenges at the technical universities. It concludes with recommendations for successful implementation of the CBT concept in all programmes across the technical universities in Ghana and other institutions of higher learning.

\section{Technical University Education in Ghana}

The establishment of polytechnics in Ghana, now known as technical universities, came at a time when there was an urgent need in the country to train highly skilled professionals with sound practical and theoretical background to take up the middle-level supervisory roles in the industry. This evolution started in the early 1960 s with an establishment of technical institutes in the country to run craft programmes (Nsiah-Gyabah, 2005). In 1963, three of these technical institutes at Accra, Kumasi and Takoradi were re-designated as polytechnics to run non-tertiary programs (Boakye-Agyeman, 2006). This was followed by Tamale and Ho in 1984 and 1986 respectively. From the 1980 s to 2000 , five other polytechnics were established at Koforidua, Cape Coast, Wa, Bolgatanga and Sunyani which brought the number of the polytechnics to ten (10) in all administrative regions in the country (Nsiah-Gyabah, 2005).

The promulgation of the polytechnic law 1992 (PNDCLaw 321) elevated the polytechnics into tertiary status and also gave them the legal backing to provide tertiary education through full time courses in the field of manufacturing, commerce, science, technology, applied social science, applied arts and technology, and such other areas as may be determined by the authority responsible for higher education with the passage of the polytechnic law 1992. In 2007, the Polytechnic Law (PNDCLaw 321 of 1992) was replaced by the Polytechnics Law (Act 745) which then gave a clear mandate to the Polytechnics to provide tertiary education in the fields of manufacturing, commerce, science, technology, applied social sciences and applied arts and also to provide opportunities for skills development, applied research and publication of research findings. These policy alignment and reforms in the polytechnic education were introduced with the aim of addressing some deficiencies in that system of education.

The CBT concept of teaching and learning in the technical universities started as a pilot programme in early 2004 in some selected polytechnics in Ghana with support from some 
development partners(Boahin, 2014). CBT concept places more emphasis on hands on training and it aims at training students to develop the skills needed to perform effectively and efficiently in the industry. It has since its introduction, trained many skilled and competent professionals in the field of engineering, built environment and applied sciences. The latest reform which became effective in 2016/17 academic year is associated with the government's policy to convert polytechnics into technical universities with a clear policy direction to train competent and highly skilled professionals that the country needs. The conversion of polytechnics into technical universities is to realignment and refocus of the polytechnic mandate to drive the economic and national development agenda (MOE, 2014). In November 2016, polytechnics in Ghana officially became the technical universities by the promulgation of the technical university Act (Act 2016).

\section{The Competency Based Training (CBT) Concept}

Competency Based Training is an industry and demand driven education and training programme based on well-defined industry generated standards in which skills, knowledge and attitudes are specified in order to define, steer and help to achieve competence standards, mostly within a kind of national qualifications framework (Anane, 2013; Deissinger \& Hellwig, 2011; ANTA, 2002). These industry standards are the basis upon which the curriculum, assessment and learning materials are designed and developed. The focus of CBT programme is on the measure of the expected output of the trainee at the workplace as opposed to the theoretical knowledge acquired. It is a training programme which ensures that learners gain the necessary knowledge, skills and attitudes or values to be successful in the working environment. It is primarily aimed at training people with the requisite skills and knowledge to meet industry specific standards rather than an individual's achievement relative to others in the group (Wolny, 1999).

Historically, the implementation of a modern competency based training concept of education in the world began in the United State of America (USA) as part of efforts to reform teacher training education in the early 1960s (Brown, 1994; Hodges and Harris, 2012). Prior to that, application of scientific management to work roles and the development of mastery learning models had already been introduced into the vocational training models during the 1920 s and 1930s ((Brown, 1994). Studies have shown that the scope of CBT system expanded and broadened to include a wide range of variables in defining competence. Factors such as job competence, personal competence and meta-competence were therefore considered the definition and determination of core task and core assignment of CBT system (LeDiest and Winterton, 2005; Cheetham and Chivers, 1996). Countries such as Australia, United Kingdom, New Zealand and Canada have adopted and implemented the formal system of CBT into their educational system (Hodges, 2007; Gammie and Joyce, 2009; Parker and Walters, 2008; Hendry et. al. 2007; Willmott 2006,). The relevance and quality of CBT system influenced the design and delivery of technical and vocational education across the globe and also led to many educational reforms in some countries including Ghana. For example, national reforms in the late 1980 s and early 1990 s in Australia required that all accredited vocational education programmes be competency based (Hodges and Harris, 2012). Many countries such as Britain, USA, New Zealand, Australia, Canada, Singapore and South Africa have also adopted the used of CBT as an effective education and training system (JICA, 2001).In 2014, the National Board for Professional and Technician Examination (NABPTEX) a regulatory body in Ghana and National Council of Technical Education (NCTE) jointly issued a directive to the technical universities to convert all programmes, especially engineering and applied sciences into the CBT concept of teaching and learning. Prior to that, CBT has already been introduced in some technical and vocational institutes in Ghana. 


\section{Characteristics of Competency Based Programmes}

The most important characteristic of CBT is that it places more emphasis on the knowledge and skills acquired rather than the time spent. Under CBT system, students' progress by demonstrating their competence, which means they prove that they have mastered the knowledge and skills (which are called competencies) required for a particular course, regardless of how long it takes. Foyster (1990); Delker (1990) and Norton (1987), have discussed extensively the key characteristics of CBT which are still relevant in the modern CBT concept. The following are some of the key characteristics of competency based programs:

a) In CBT system, the required competencies in the field of study must be carefully selected,

b) Supporting theory is integrated with skill practice and the essential knowledge is learned to support the performance of skills,

c) Detailed training materials are key to the competencies to be achieved and are designed to support the acquisition of knowledge and skills,

d) Methods of instruction involve mastery learning, the premise that all participants can master the required knowledge or skill, provided sufficient time and appropriate training methods are used,

e) Participants' knowledge and skills are assessed as they enter the program and those with satisfactory knowledge and skills may bypass education and training or competencies already attained,

f) Flexible training approaches including large group methods, small group activities and individual study are essential components, and

g) Satisfactory completion of training is based on achievement of all specified competencies.

A well-structured CBT system is designed to benefit both the employee and the employer. One of the benefits of the CBT system is that, it ensures that cooperate training and professional development activities are cost effective, goal oriented and productive for the employer, it enables employees to be more proactive beyond their individual roles by learning additional skills that are valued by the organisation. CBT also improves communication between employees and management and also sets clear expectations for employees, enabling them to make better decisions and work effectively (The Competency Group, 2016).

\section{CBT Programmes in Ghana Technical Universities}

The purpose of introducing CBT into technical and vocational education in Ghana education system is to train highly skilled and competent people in the country to serve as a catalyst for industrial development and transformation of industries for the socio-economic development(G.Afeti, et al., 2003)(Afeti et al 2003). CBT concept of teaching and learning with the support from some donor agencies and National Board for Professional and Technician Examination is being piloted in some selected programmes in the technical universities in Ghana. Table 1.0 gives the list of programs in the technical universities where CBT has been implemented in Ghana. In 2006, Civil Engineering departments of Kumasi and Takoradi technical universities implemented CBT concept of teaching and learning with a support from the Netherlands Organization for International Cooperation in Higher Education (NUFFIC). Japan Internal Cooperation Agency (JICA) and other development partnershave funded and supported the implementation and development of some CBT programmes in other technical universities in the country. The conversion of the polytechnics into technical universities coincided with the policy guidelines that seek to convert all programmes in these institutions to the competency based training system of teaching and learning. This directive policy has had a total endorsement by all stakeholders in the technical universities in Ghana. 
Table 1.o - CBT programmes in Ghana technical universities

\begin{tabular}{|c|c|c|c|}
\hline ID & POLYTECHNIC & PROGRAMMES & DONOR AGENCY \\
\hline $\mathbf{1}$ & Accra Technical University & HND Fashion & NUFFIC, (Netherland) \\
\hline 2 & $\begin{array}{l}\text { Bolgatanga Technical } \\
\text { University }\end{array}$ & $\begin{array}{l}\text { HND Agricultural } \\
\text { Engineering }\end{array}$ & NUFFIC, (Netherland) \\
\hline 3 & $\begin{array}{l}\text { Cape Coast Technical } \\
\text { University }\end{array}$ & $\begin{array}{l}\text { HND Building } \\
\text { Technology }\end{array}$ & $\begin{array}{l}\text { Hybrid, (Netherland \& } \\
\text { Australia) }\end{array}$ \\
\hline 4 & Ho Technical University & $\begin{array}{l}\text { HND Agricultural } \\
\text { engineering }\end{array}$ & NUFFIC, (Netherland) \\
\hline 5 & Kumasi Technical University & $\begin{array}{l}\text { HND Civil engineering; } \\
\text { BTech Civil Engineering } \\
\text { BTech Chemical } \\
\text { Engineering }\end{array}$ & NUFFIC, (Netherland) \\
\hline 6 & $\begin{array}{l}\text { Koforidua Technical } \\
\text { University }\end{array}$ & $\begin{array}{l}\text { HND Civil engineering, } \\
\text { HND Mechanical } \\
\text { Engineering, } \\
\text { HND Energy System } \\
\text { HND Hospitality } \\
\text { Management }\end{array}$ & NUFFIC, (Netherland) \\
\hline 7 & Sunyani Technical University & $\begin{array}{l}\text { HND Building } \\
\text { technology } \\
\text { BTech Building } \\
\text { technology }\end{array}$ & $\begin{array}{l}\text { Hybrid, (Netherland \& } \\
\text { Australia) }\end{array}$ \\
\hline 8 & Takoradi Technical University & $\begin{array}{l}\text { HND Civil engineering } \\
\text { BTech Civil Engineering }\end{array}$ & NUFFIC, (Netherland) \\
\hline 9 & Tamale Technical University & $\begin{array}{l}\text { HND Agricultural } \\
\text { Engineering }\end{array}$ & NUFFIC, (Netherland) \\
\hline 10 & Wa Technical University & $\begin{array}{l}\text { HND Agricultural } \\
\text { Engineering } \\
\text { HND Civil Engineering }\end{array}$ & NUFFIC, (Netherland) \\
\hline
\end{tabular}

\section{Advantages of CBT over the Subject based system}

The CBT system has numerous advantages over the traditional subject based system of teaching and learning in technical and vocational education in Ghana. Key among them are in areas of curriculum structure and development, mode of delivery, student's qualification, promotion and assessment of students. In the subject or course based system, student qualification indicates that the holder has successfully completed a course, but do not indicate the level of competences, the qualification of CBT candidate is based on the achievement of specific competences to specific standards. The qualification proves holder's ability to do a wide range of jobs and give proof that specific knowledge has been acquired. Curriculum structure is also a key component in the CBT scheme. In the traditional subject based approach, curriculum is structured and administered on the basis of time spent in training and the expectation that knowledge would be gained whereas in the CBT system, curriculum structure is based on competences derived from industry needs based on endorsed national standards. Candidates are assured of consistency in the awards and national standards are enforced to achieve the desired results. Students' assessment is one area where CBT system has comparative advantage over the traditional subject based system. In the traditional system, students are assessed based their ability to write and pass a routine type of semester examination whereas in the CBT system 
candidate's assessment is directly related to the achievement of competences specified on modular system. Another area of great significance is the promotion of students from one level onto another. In the traditional system, promotion is based on the candidate's ability to pass a written exam and met some criteria for the promotion, including minimum credits and cumulative grade point average acquired. The CBT system on the other hand promotes candidates based on the competency levels on the specific task assigned.

\section{CBT Implementation Challenges in the Technical Universities}

One of the teething challenges of the implementation of competency based training system in the technical universities was with the interpretation of student's academic transcripts and grading system adopted by the institutions which is different from the traditional grading system known by industry and academia. In the CBT grading system, a student's performance is graded as a competent when he/she passes all required courses and scores accumulative raw score average of $50 \%$ to $100 \%$, and graded not competent when scores cumulative raw score average ofo\% to $49.99 \%$ as shown in table 2.

Table 2 - CBT course grading

\begin{tabular}{lll}
\hline Score Obtained & Status & Letter Designation \\
$50 \%-100 \%$ & Competent & C \\
$0 \%-49.99 \%$ & Not Competent & NC \\
& & \\
\hline
\end{tabular}

Some industries and academic institutions in the country were not admitting CBT graduates because they did not understand what the competent and not yet competent mean and its equivalence when compared to the traditional system of first class and second-class designations. This has compelled the regulatory bodies to come out with some class designations in the CBT certification grading. Although the challenge attributed to the grading system have reduced due to the general acceptance of the CBT concept, a section of the academic staff interviewed believes that the traditional system is the best because there is no class designation in the CBT system adopted by the institution. The findings from the interview conducted on the implementation of CBT system in addition to the CBT grading system have been grouped into four (4) broad categories as shown in figure 1. Inadequate funding to the technical universities is the major implementation challenges. The other three are lack of institutional support, infrastructural challenges and lack of proper documentation from the regulatory institutions. These challenges are further explained in the following subsections.

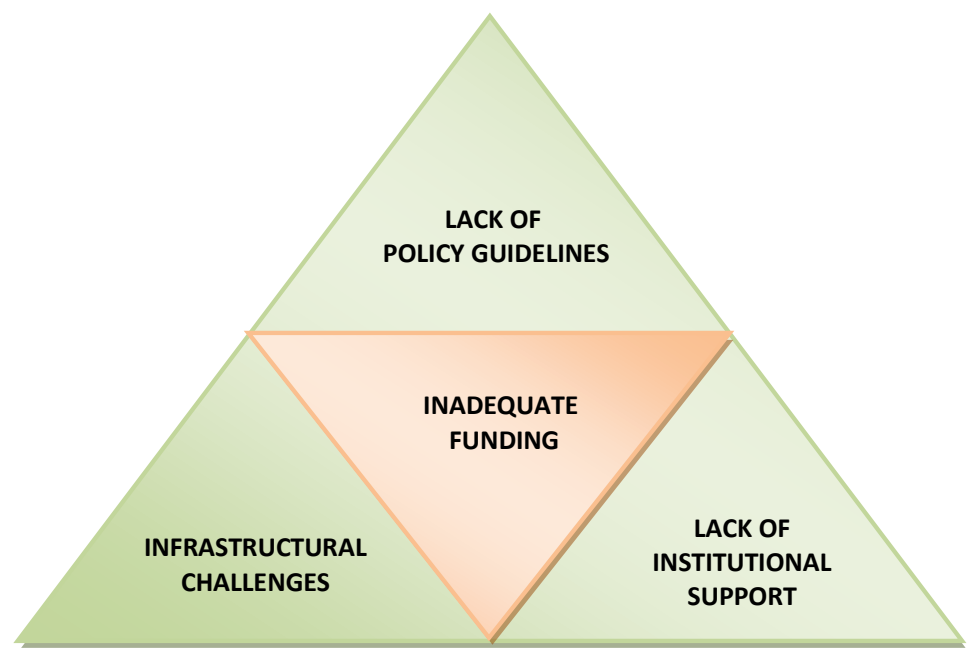


Figure 1- CBT implementation challenges in Ghana technical universities

\section{Inadequate funding}

One of the major challenges confronting CBT implementation in technical university education is inadequate financial support to the CBT departments in the institutions. The study revealed that inadequate funding is the cause of all the identified implementation challenges in CBT programmes. Effective implementation of CBT concept of teaching and learning requires continuous flow of funds in support of the following key activities:

- Training for lecturers and staff running CBT programmes in the technical universities,

- Refresher courses and industrial training for newly recruited staff and lecturers,

- Acquisition and maintenance of hardware and software packages for teaching and learning at the engineering and applied sciences,

- Infrastructural development such as laboratories, workshops and studios,

- Procurement and installations of laboratory equipment and instrument for practical and laboratory works,

- Curriculum development and the preparation of instructional materials.

Inadequate funding has greatly affected these activities which are necessary in the CBT implementation processes. Major sources of funding to these technical universities and other tertiary institutions in the country are government's budgetary allocations, Ghana Education Trust Fund (GETFund) introduced in 2001, development partners, contributions from private sector ' and Internally Generated Fund (IGF) by individual institutions. Comparatively, budgetary support to the technical universities including GETFund allocation is far less than that of the public universities in the country. For example, between 2001 and 2009, the ten polytechnics (now technical universities)received $21.56 \%$ of government budgetary allocation while public universities received $73.86 \%$ during the same period (Iddrisu et. al. 2014). Although the introduction of GETFund has greatly supported the education subsector through infrastructure development and provision of equipment and instrument over the years, not much has been done in the technical universities in term of infrastructural development.

\section{Infrastructural challenges}

The sustenance of CBT programs relies greatly on equipping the training institutions with the needed infrastructure and basic teaching tools. The measure of competencies of CBT trainees depends on the ability to demonstrate their knowledge and skills on the job defined by the core tasks and assignments. This requires continuous practice with tools, equipment and laboratory works. In many instances, the technical universities lack the needed infrastructure including laboratories for academic works for both students and lecturers and tools to support students in their training goals. The acquisition and maintenance of hardware and software packages in the field of engineering, sciences and commerce coupled with increasing cost of equipment, tools and facilities in laboratories and workshops have been the main infrastructural challenges in the CBT implementation and development in the technical universities.

\section{Lack of institutional support}

The initial training and follow-ups assistance provided for educators must be systematic in order to avoid the tendency for the trainers to teach (as in the subject based approach) and CBT trainers quickly slip back into the role of the traditional teacher (Sullivan, 1995). In order to overcome this limitation, there must be the need to provide regular capacity building workshops and training for staff in the training institution. Lack of institutional support for the organisation of workshops and training seminars on CBT for lectures and supporting staff have been one of the limitations of CBT. For example, it was revealed that the initial training of CBT system delivery and implementation for the staff of mechanical engineering department at Accra 
technical university was sponsored by Japan Internal Cooperation Agency (JICA) for three years. After three years of its implementation, the programme was stopped due to inadequate funding from the institution. CBT programs therefore require periodic training for the educators and this must be supported by the management of these technical universities.

Another unique feature of the CBT system is the role of industry and professional bodies in the training of CBT students. The students spend six months in industry during attachment and an entire semester for a live project which is jointly supervised by academic supervisors and supervisors from industry. The challenge in recent times had been the difficulty in finding attachment placement for some students and live projects for final year. In addition to this, lack of institutional support for students during final year live projects has been a major drawback. During live projects, students are supposed to travel to their project sites, take samples for analysis and carry out field measurement. Some external institutions are increasingly becoming reluctant to take students on board on the basis that they do not have budget to adequately support them especially during their live project work.

\section{Lack of policy guidelines}

The study further revealed that there are no proper documentation and policy guidelines regulating the conduct and assessment of examination and promotion of students in CBT programmes in the technical universities. In CBT concept of teaching and learning, the computation of student's performance is different from the traditional way of assessing, grading and promoting students where classes are used. Whereas the other systems like Grade Point Average (GPA) and Cumulative Weighted Average (CWA) include credit hours in their calculation, Raw Score Average (RSA) used in the CBT concept on the other hand does not use course credit hours in assessing student's performance. These must be properly documented to aid students and lecturers in the conduct of CBT examination, assessment and promotion from the regulatory body.

\section{Recommendations and the way forward}

Although CBT implementation and development came with its own challenges in the technical universities, it has greatly contributed immensely in the training of highly skilled and competent graduates needed to feed the growing industry in the country and the sub region. However, these challenges need to be addressed for smooth and effective implementation and development of CBT concept of teaching and learning in the country. The following are some recommendations that would help to improve CBT implementation in the technical universities.

\section{Increase budgetary allocation to technical universities}

Inadequate funding and budgetary support to the technical universities over the years has greatly affected the implementation of CBT programs in Ghana. An increase in budget allocation from the central government and GETFund allocations to the department and faculties practicing CBT system would be needed to support the successful implementation of the concept. There must be enough budgetary funds for capacity building for staff members, the procurement of consumables in the laboratories and also to support the running and organisation of workshops, seminars and kick-offs for students and staff in the departments that run programmes under CBT. For the technical universities to meet its developmental goals in the delivery of technical education at the tertiary level, including the full implementation of CBT at all levels in the technical education setup, there must be an increase in budgetary allocations from government, GETFund, development partners and other stakeholders. 


\section{Strengthening industrial and professional collaboration}

The inputs from industries and professional bodies have been very beneficial in the training of students on CBT programmes in the technical universities. They have been actively involved in the design of CBT curriculum, development and the identification and definition of various skills and knowledge needed. The collaboration between the technical universities and industries in the development and implementation of CBT programs must therefore be strengthened. It is evidently clear that, successful development and implementation needs total support of the industry. The industry and professional bodies must continue to support CBT departments in the area of internship for students and also for staff to be abreast with current developments in the job market.

\section{Improvement in infrastructure for teaching and learning}

The structure of CBT programme requires the need to provide adequate infrastructure and facilities to support teaching and learning. In the CBT concept of teaching and learning, students are grouped to work on modular projects to demonstrate their knowledge, skills and competencies in the subject area by performing specific core tasks and assignments. This put more pressure on the limited facilities in the institutions. The study revealed that there is inadequate infrastructure in the various campuses of the technical universities to support full scale implementation of CBT especially at the faculties of engineering, built environment and applied sciences. In order to ease the pressure on these limited facilities and also to improve teaching and learning of CBT in the technical universities, there must be that conscious effort by the government, management of the institutions and other stakeholders to improve the learning environment in various campuses.

\section{Development of policy guidelines}

The implementation of CBT started without any policy document to regulate the activities of the programmes in the technical universities. Individual departments developed their own policy guidelines approved by the academic boards of their respective universities. Currently, there is no policy document about the conduct, assessment promotion and grading of CBT programs in the polytechnic from the regulating institution. A handbook detailing the interpretation of raw score calculation, raw score averages, progression and grading of students must be developed and documented to assist students and lectures in CBT programmes.

\section{Conclusions}

The Competency Based Training concept of teaching and learning was introduced into the technical universities in Ghana with the aim of training highly competent people in the country to serve as a catalyst for industrial development and transformation of industries for the socio economic development. It has contributed immensely to the training of highly skilled graduates needed in the industry. In spite of its numerous advantages and prospects, there are some implementation challenges that have been outlined and discussed in this paper that need to be considered for smooth and effective implementation in country's technical universities. Inadequate funding to the institution, lack of infrastructure development and institutional support needs to be addressed in addition to the development of policy guidelines. This notwithstanding, CBT approach to teaching and learning is currently gaining popularity among many stakeholders in the education circles. The recommendations of the study discussed in this paper would help to improve CBT implementation and development in the technical universities in particular and technical and vocational education in Ghana in general. 


\section{References}

i. Anane, C. A., 2013. Competency Base Training: Quality delivery for Technical and Vocational Education and Training (TVET) Institutions.. Education Research International, 2(2), pp. 117-127.

ii. Australian Chamber of Commerce and Industry (ACCI) , 1992. The Australian national training system: Guidelines for Employers, Melbourne: s.n.

iii. Australian National Training Authority (ANTA), 2002. A Licence to Skill: The Implications for the Implementation of Training Packages. Brisbane: s.n.

iv. $\quad$ Boahin, P., 2014. Competency-Based Training in higher education: towards an implementation in Ghanain polytechnics, Groningen: s.n.

v. Boakye-Agyeman, N., 2006. Polytechnic Education in Ghana: The Case of the HND Estate Management Programme.. Accra, 5th FIG Regional Conference.

vi. $\quad$ Brown, M., 1994. An introduction to the discourse on competency-based training (CBT) . In: D. U. C. D. Centre, ed. A collection of readings related to competency-based training . Victoria, Australia: Victorian Education Foundation, pp. 1-17.

vii. Butova, Y., 2015. The history of development of competency-based education. European Scientific Journal, p. $1857-7881$.

viii. Cheetham, G. \& Chivers, G., 1996. Towards a holistic model of professional competence.. Journal of European Industrial Training, 20(5), pp. 20-30.

ix. $\quad$ Deissinger, T. \& Hellwig, S., 2011. Structures and functions of competency-based education and training (CBET), Mannheim, Germany: A comparative perspective.

x. $\quad$ Delker, P., 1990. Basic Skills Education in Business and Industry :Factors for Success or Failure., s.l.: Office of Technology Assessment, United States Congress. .

xi. $\quad$ Foyster, J., 1990. Getting to Grips with Competency-Based Training and Assessment, Leabrook, Australia: TAFE National Centre for Research and Development.

xii. G.Afeti, Baffour-Awuah, D. \& Budu-Smith, J., 2003. Baseline Survey for the Introduction of Competency - Based Training in Polytechnics, National Council forTertiary Education (NCTE), s.l.: Japan Internal Cooperation Agency (JICA).

xiii. Gammie, E. \& Joyce, Y., 2009. Competence-based approaches to the assessment of professional accountancy training work experience requirements. The ICAS experience. Accounting education,, 18(4-5), p. 443-466.

xiv. Hendry, C., Lauder, W. \& Roxburgh, M., 2007. The dissemination and uptake of competency frameworks.. Journal of Research in Nursing, Volume 12, p. 689.

xv. Hodge, S., 2007. The origins of competency-based training. Australian Journal of Adult Learning, 47(2), p. 179-209.

xvi. Hodge, S. \& Harris, R., 2012. Discipline, governmentality and 25 years of competency-based training.. Studies in the Education of Adults, 44(2).

xvii. Iddrisu, S., Alhassan, E. \& Kinder, T., 2014. Polytechnic Education In Ghana. Management Delivery And Challenges , 1(6), pp. $411-424$.

xviii. Japan International Cooperation Agency (JICA), 2001. Study of Development of Master Plan to Strengthen technical Education in the Republic of Ghana, s.l.: s.n. 
xix. LeDeist, F. \& Winterton, J., 2005. What is competence?. Human Resource Developmental International, 8(1), pp. 27-46.

xx. Ministry of Education (MOE), 2014. Report of the Technical Committee on Conversion of the Polytechnics in Ghana to Technical Universities. [Online] Available at: www.moe.gov.gh/assets/media/docs [Accessed April 2015].

xxi. Norton, R., 1987. Competency-Based Education and Training. A Humanistic and Realistic Approach to Technical and Vocational Instruction., Chiba City, Japan: Paper presented at the Regional Workshop on Technical/Vocational Teacher Training.

xxii. Nsia-Gyabaah, K., 2005. Polytechnic Education in Ghana. The Past, The Present and The Future, s.l.: A Paper presented at the Kick-Off Conference.

xxiii. $\quad$ Parker, B. \& Walters, S., 2008. Competency based training and national qualifications frameworks. Insights from South Africa, 9(1), pp. 70-79.

xxiv. Polytechnic Act, 2007. Act 745, s.l.: Polytechnic Act.

xxv. Polytechnic Law, 1992. PNDC Law 321, s.l.: Polytechnic Law.

xxvi. $\quad$ Sullivan, R., 1995. The Competency-Based Approach to Training. s.l.: United States Agency for International Development (USAID), JHPIEGO Corporation.

xxvii. The Competency Group , 2016. www.competencygroup.com. [Online] Available at: www.competencygroup.com [Accessed october 2015].

xxviii. Willmott, G., 2006. The development of a high-skilled workforce through a national Workforce Skills Qualifications System: The Singapore experience. Beijing, Paper presented at the ILO International forum on Chinese High-Skilled Workers.

xxix. Wolny, M., 1999. Competency Based Training and in the Aviation Environment. [Online] Available at: $\quad$ www.casa.gov.au/wcmswr/assets/main/seminars/cbt aviation.pdf. [Accessed September 2015]. 